\title{
Effects of Diet after Early Breast Cancer Treatment: A Systematic Review and Meta-Analysis of Clinical Trials
}

\author{
Henrique de Araújo Vianna Träsel ${ }^{a, b}$ Frederico Soares Falcettab, c \\ Fernando Kude de Almeida $^{a}$ Mariana Rangel Ribeiro Falcetta ${ }^{b} d$ \\ Rodrigo Antonini Ribeiro ${ }^{e}$ Daniela Dornelles Rosa ${ }^{a}, f$ \\ a Post-Graduate Program of Pathology, Universidade Federal de Ciências da Saúde de Porto Alegre,

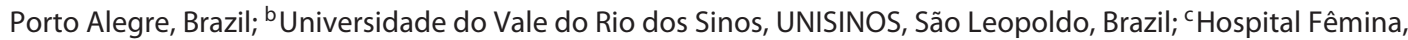

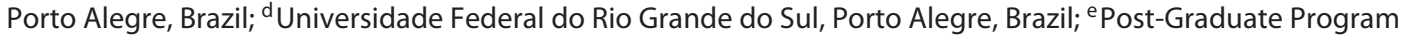 \\ in Epidemiology, Universidade Federal do Rio Grande do Sul, Porto Alegre, Brazil; ${ }^{f}$ Hospital Moinhos de Vento, \\ Porto Alegre, Brazil
}

\section{Keywords}

Breast neoplasms · Diet therapy · Meta-analysis · Mortality · Disease-free survival

\begin{abstract}
Purpose: Randomized clinical trials (RCT) are inconclusive regarding the role of dietary interventions in anthropometric measurements and survival in breast cancer patients. Our aim was to conduct a systematic review and meta-analysis to assess the effects of diet on these outcomes in women treated for early-stage breast cancer. Methods: Embase, MEDLINE, the Cochrane Database of Systematic Reviews, and the Cochrane Central Register of Controlled Trials were searched for RCT comparing dietary interventions (individualized dietary counseling, prescription of a specific diet, or others) with usual care in women that were treated for early breast cancer. Primary outcomes were overall survival (OS) and disease-free survival (DFS); secondary outcome was a change in body mass index (BMI). Results: We found 12 RCT eligible for analysis, 7 of which were included in the quantitative analysis. Two studies reported OS and DFS and 6 reported BMI data. The hazard ratio (HR) for OS and DFS was 0.91 (95\% confidence interval $[\mathrm{Cl}] 0.77-1.07, p=0.25$ ) and 0.92 (95\% Cl 0.79-1.08, $p=0.31$ ) for the intervention and control groups, respectively. Intervention was associated
\end{abstract}

with $\mathrm{BMI}$ reduction in subjects who received a specific diet instead of counseling or other types of intervention (-0.67; $95 \% \mathrm{Cl}-1.14$ to -0.21$)$. Conclusions: Despite increasing survival among breast cancer patients due to better oncological treatments, there is still a lack of prospective data regarding the effects of dietary interventions in this population. We found positive association between prescription of specific diets in terms of anthropometric measures; there were no differences in OS or DFS.

\footnotetext{
(c) 2021 S. Karger AG, Basel
}

\section{Introduction}

Breast cancer is the major cancer among women worldwide and the leading cause of death in many countries $[1,2]$. Despite advances in medical, surgical, and radiation treatments as well as in screening methods, around $30 \%$ of all initial breast cancer cases will recur.

Approximately half of breast cancer patients in Western countries are overweight or obese at the time of diagnosis [3]. Moreover, up to $60 \%$ of women will gain weight during oncological treatment [4]. Obesity and weight gain after the diagnosis are related to poor overall survival (OS) and disease-free survival (DFS) $[5,6]$. Physical activity and dietary interventions limit weight gain among 


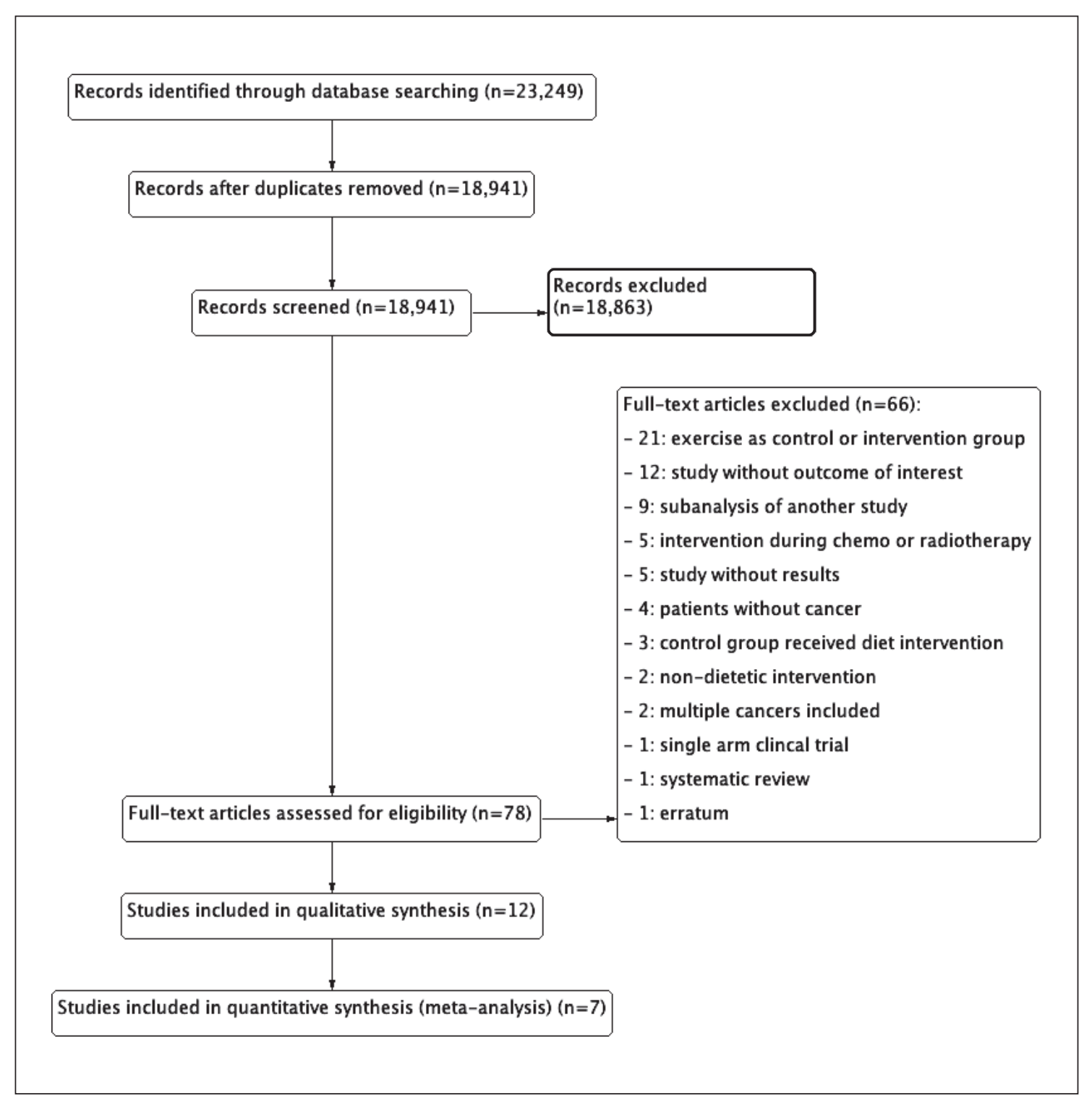

Fig. 1. PRISMA flow chart. Created by Review Manager 5.3.

breast cancer patients [7], which can improve outcomes and contribute to reducing breast cancer-specific mortality, according to observational studies [8]. There is 1 clinical trial that assessed physical interventions and mortality in early breast cancer showing better OS and DFS with the interventions $[9,10]$.

Observational studies show that the quality of the diet could reduce the risk of breast cancer recurrence, but none assessed the risk of death $[11,12]$. There are scant data about dietary interventions and their relationship with outcomes in early breast cancer patients.

We aimed to conduct a systematic review and metaanalysis to assess the effects of dietary interventions in anthropometric measures and survival in women after the treatment of early breast cancer.

Effects of Diet after Early Breast Cancer Treatment

\section{Materials and Methods}

Protocol

The protocol of this systematic review and meta-analysis was publishedpreviously[13] (PROSPEROregistryCRD42014008743). The systematic review was conducted according to the Cochrane Handbook for Systematic Reviews of Interventions (CHSRI) [14] and the data reported according to PRISMA recommendations [15].

\section{Data Sources}

The electronic databases Embase, MEDLINE, Cochrane Database of Systematic Reviews, and Cochrane Central Register of Controlled Trials were consulted for indexed literature including papers, abstracts, or reports up to May 2020 (online suppl. Material; see www.karger.com/doi/10.1159/000514469 for all online suppl. material, Search Strategy). We also searched in the grey literature in the annals of meetings and ongoing trials at ClinicalTrials.gov. 
Table 1. Characteristics of the studies

\begin{tabular}{|c|c|c|c|}
\hline $\begin{array}{l}\text { First author [ref.], year } \\
\text { Study location, cohort }\end{array}$ & Sample & Intervention characteristics & Outcomes \\
\hline $\begin{array}{l}\text { Chlebowski [20], } 1987 \\
\text { USA, } 7 \text { centers }\end{array}$ & $\begin{array}{l}49 \text { women } \\
\text { Stage II BC with } \geq 1 \text { positive axillary nodes } \\
\text { ER-positive: } 32 \text {; PR-positive: } 10 \text {; unknown: } 7 \\
\text { Mean age } 60.3 \text { years } \\
\text { Mean \% ideal BMI: } 114.5 \% \\
\text { Time from surgery to randomization: }<60 \text { days }\end{array}$ & $\begin{array}{l}\text { 3-month intervention } \\
\text { (1) Intervention: prescription of diet with a target of } 15 \% \text { of } \\
\text { caloric intake derived from fat. Nutritional counseling every } \\
2 \text { weeks for } 3 \text { months, and then monthly appointments until } \\
12 \text { months. } \\
\text { (2) Control: maintenance of basal fat intake around } 38 \% \text { of } \\
\text { total calories. Nutritional counseling every } 3 \text { months for } 1 \text { year }\end{array}$ & $\begin{array}{l}\text { Change from baseline to } 6 \text { months: } \\
\text { (1) Weight: }-2.4 \mathrm{~kg} 2.96, p=0.001 \\
\text { (2) Weight: }-1.2 \mathrm{~kg} 3.74, \mathrm{~ns}\end{array}$ \\
\hline $\begin{array}{l}\text { Holm et al. [19], } 1990 \\
\text { Sweden, } 3 \text { centers }\end{array}$ & $\begin{array}{l}240 \text { women } \\
\text { Stages I (33\%) and II ( } 61 \%) \text { BC } \\
\text { Premenopausal: } 12 \% \\
\text { Postmenopausal: } 85 \% \\
\text { Mean age } 58 \text { years } \\
\text { BMI } \geq 25: 34 \% \\
\text { Time to randomization: not supplied }\end{array}$ & $\begin{array}{l}\text { 24-month intervention } \\
\text { (1) Intervention: individualized dietary counseling to reduce } \\
\text { fat to } 20-25 \% \text { of total caloric intake while increasing } \\
\text { carbohydrate intake. No change in total energy intake. } \\
\text { Counseling every } 3 \text { months during the first year. } \\
\text { (2) Control: usual care to maintain baseline fat intake }\end{array}$ & $\begin{array}{l}\text { Change from baseline to } 24 \text { months: } \\
\text { (1) Weight: }-0.4 \mathrm{~kg} \\
\text { (2) Weight: } 1.3 \mathrm{~kg} \\
p<0.05\end{array}$ \\
\hline $\begin{array}{l}\text { Rock [23], } 2004 \\
\text { USA, } 7 \text { centers } \\
\text { (WHEL subgroup) }\end{array}$ & $\begin{array}{l}291 \text { women } \\
\text { Stage I-IIIA BC patients who underwent } \\
\text { surgery, lymph } \\
\text { node dissection, and radiotherapy } \\
\text { Mean age } 54.9 \text { years } \\
\text { Mean BMI } 27.6 \\
\text { Time from diagnosis to randomization: } \\
23.5 \text { months }\end{array}$ & $\begin{array}{l}\text { 12-month intervention } \\
\text { WHEL protocol }\end{array}$ & $\begin{array}{l}\text { Change from baseline to } 12 \text { months: } \\
\text { Intervention group: } \\
\text { Energy: }-79 \mathrm{kcal} / \text { day } \\
\% \text { energy from fat: }-7 \% \\
\text { Weight: } 0.0 \mathrm{~kg} \\
\text { BMI: } 0.0 \\
\text { Estradiol: }-27 \mathrm{pmol} / \mathrm{L} \\
\text { Testosterone: } 0.0 \mathrm{nmol} / \mathrm{L} \\
\text { SHBG: }+0.05 \mu \mathrm{mol} / \mathrm{L} \\
\text { Control group: } \\
\text { Energy: }-146 \mathrm{kcal} / \text { day } \\
\% \text { energy from fat: }-1 \% \\
\text { Weight: }+1.0 \mathrm{~kg} \\
\text { BMI: }+0.1 \\
\text { Estradiol: }+5.0 \mathrm{pmol} / \mathrm{L} \\
\text { Testosterone: } 0.0 \mathrm{nmol} / \mathrm{L} \\
\text { SHBG: }-0.03 \mu \mathrm{mol} / \mathrm{L}\end{array}$ \\
\hline $\begin{array}{l}\text { Thomson [22], } 2005 \\
\text { USA, } 1 \text { center } \\
\text { (WHEL subgroup) }\end{array}$ & $\begin{array}{l}52 \text { women from the Arizona site of the WHEL } \\
\text { study } \\
\text { Mean age } 53.6 \text { years } \\
\text { Time from diagnosis to randomization: } \\
23.5 \text { months }\end{array}$ & $\begin{array}{l}\text { 48-month intervention } \\
\text { WHEL protocol }\end{array}$ & $\begin{array}{l}\text { Change from baseline to } 48 \text { months: } \\
\text { Intervention group: } \\
\text { BMI: }+0.7 \\
\text { Waist-to-hip ratio: }+0.03 \mathrm{~cm} \\
\text { Body fat: }+1.0 \% \\
\text { Control group: } \\
\text { BMI: }+2.1 \\
\text { Waist-to-hip ratio: }+0.02 \mathrm{~cm} \\
\text { Body fat: }+2.0 \%\end{array}$ \\
\hline $\begin{array}{l}\text { Chlebowski [18], } 2006 \\
\text { USA, } 39 \text { centers } \\
\text { (WINS) }\end{array}$ & $\begin{array}{l}2,437 \text { women } \\
\text { Stage I and II unilateral resected BC } \\
\text { Baseline fat intake } 20 \%+\text { of total calories } \\
\text { Premenopausal: } 34.8 \% \\
\text { Postmenopausal: } 64.2 \% \\
\text { Unknown: } 1 \% \\
\text { ER-positive: } 80 \% \text {; PR-positive: } 66 \% \\
\text { Mean age } 58.5 \text { years } \\
\text { Mean BMI } 27.5 \\
\text { Time to randomization: not supplied }\end{array}$ & $\begin{array}{l}\text { 60-month intervention } \\
\text { (1) Intervention: low-fat eating plan, i.e., }<20 \% \text { of total calorie } \\
\text { intake. Regular appointments with a registered dietician. } \\
\text { Instructed to keep written record of fat intake daily. } \\
\text { (2) Control: one baseline visit to a dietitian. Received written } \\
\text { information on nutritional adequacy. }\end{array}$ & $\begin{array}{l}\text { Follow-up at } 60 \text { months: } \\
(1):(2)-\text { total group: } \\
\text { OS: HR } 0.89(0.65-1.21, p=0.56) \\
\text { DFS: HR } 0.81(0.65-0.99, p=0.007) \\
\text { (1):(2) - ER-negative group: } \\
\text { RFS 0.58 }(0.37-0.91) \\
\text { Change from baseline to } 12 \text { months } \\
\text { (1) Weight: }-2.1 \mathrm{~kg} \\
\text { BMI: }-0.8 \\
\text { (2) Weight: }+0.2 \mathrm{~kg} \\
\text { BMI: }+0.1\end{array}$ \\
\hline $\begin{array}{l}\text { Blackburn [25], } 2007 \\
\text { USA, } 3 \text { centers } \\
\text { (WINS subgroup) }\end{array}$ & $\begin{array}{l}53 \text { women } \\
\text { Time to randomization: not supplied }\end{array}$ & $\begin{array}{l}60 \text {-month intervention } \\
\text { WINS protocol }\end{array}$ & $\begin{array}{l}\text { Change from baseline to } 24 \text { months: } \\
\text { Intervention group: } \\
\text { Insulin: }-6.1 \mu \mathrm{U} / \mathrm{mL} \\
\text { Control group: } \\
\text { Insulin: }-7.7 \mu \mathrm{U} / \mathrm{mL}\end{array}$ \\
\hline $\begin{array}{l}\text { Pierce [26], } 2007 \\
\text { USA, } 7 \text { centers } \\
\text { (WHEL) }\end{array}$ & $\begin{array}{l}3,088 \text { women } \\
\text { Stage I-IIIA BC patients who underwent } \\
\text { surgery, lymph } \\
\text { node dissection, and radiotherapy } \\
\text { Stage I: } 1,191(38.5 \%) \text {, stage II: } 1,743 \text { ( } 56.5 \%) \text {, } \\
\text { and stage III: } 154(5 \%) \\
\text { ER-positive: } 2,269(73.5 \%) \text {, PR-positive: } 2,032 \\
\text { (55.8\%), and ER/PR-negative: } 619(20 \%) \\
\text { Mean age } 53.1 \text { years } \\
\text { Mean body weight } 73.4 \mathrm{~kg} \\
\text { Time from diagnosis to randomization: } \\
23.5 \text { months }\end{array}$ & $\begin{array}{l}\text { 12-month intervention } \\
\text { (1) Intervention: diet with increased intake of fiber, vegetables, } \\
\text { and fruit, and a reduced fat intake, i.e., } \\
\text { per day: } 5 \text { vegetables servings, } 3 \text { fruit servings, } 475 \mathrm{~mL} \\
\text { vegetable juice, } 30 \mathrm{~g} \text { fiber. } 15-20 \% \text { total calorie intake from fat } \\
\text { (2) Control: general daily dietary recommendations: } 5 \text { servings } \\
\text { of fruits and vegetables, } 20 \mathrm{~g} \text { fiber, and } 30 \% \text { energy from fat }\end{array}$ & $\begin{array}{l}\text { Follow-up at } 87.6 \text { months: } \\
(1):(2) \\
\text { OS: HR } 0.91(0.72-1.15, p=0.43) \\
\text { IBCE: HR } 0.96(0.80-1.14, p=0.63) \\
\text { Change from baseline to } 72 \text { months: } \\
\text { (1) Weight: }+0.6 \mathrm{~kg} \\
\text { (2) Weight: }+0.4 \mathrm{~kg}\end{array}$ \\
\hline
\end{tabular}


Table 1 (continued)

\begin{tabular}{|c|c|c|c|}
\hline $\begin{array}{l}\text { First author [ref.], year } \\
\text { Study location, cohort }\end{array}$ & Sample & Intervention characteristics & Outcomes \\
\hline $\begin{array}{l}\text { Chlebowski [27], } 2008 \\
\text { USA, } 39 \text { centers } \\
\text { (WINS) }\end{array}$ & $\begin{array}{l}2,437 \text { women } \\
\text { Time to randomization, not supplied }\end{array}$ & $\begin{array}{l}60 \text {-month intervention } \\
\text { WINS protocol }\end{array}$ & $\begin{array}{l}\text { Follow-up at } 108 \text { months: } \\
\text { (Intervention):(Control) - total group: } \\
\text { OS : HR } 0.83(0.59-1.03, p=0.14) \\
\text { (Intervention):(Control) }- \\
\text { ER-/PR- negative patients } \\
\text { Cumulative mortality: } 7.5 \text { vs. } 18.1 \% \text {, } \\
\text { RR } 0.41, p=0.003\end{array}$ \\
\hline $\begin{array}{l}\text { Cho [28], } 2014 \\
\text { South Korea, } 1 \text { center }\end{array}$ & $\begin{array}{l}61 \text { women } \\
\text { Stage I-III BC patients who had completed } \\
\text { treatment } \\
\text { Premenopausal: } 10(16 \%) \\
\text { Postmenopausal: } 41(84 \%) \\
\text { Mean age } 46.1 \text { years } \\
\text { Mean BMI } 22.9 \\
\text { Time to randomization: not supplied }\end{array}$ & $\begin{array}{l}\text { 8-week intervention } \\
\text { (1) Intervention: } 2 \text { nutritional counseling sessions and } 1 \\
\text { cooking session to encourage participants to eat at least } \\
10 \text { servings of fruits and vegetables per day } \\
\text { (2) Control: brochures supplied with recommendations for } \\
\text { a phytochemical-rich diet }\end{array}$ & $\begin{array}{l}\text { Change from baseline to } 8 \text { weeks: } \\
\text { (1) Weight: }+0.2 \mathrm{~kg} \\
\text { BMI: }+0.1 \\
\text { FACT-BQoL: }+0.7 \text { points } \\
\text { (2) Weight: }+0.3 \mathrm{~kg} \\
\text { BMI: }+0.1 \\
\text { FACT-B QoL: }+1.8 \text { points }\end{array}$ \\
\hline $\begin{array}{l}\text { Ramirez. [17], } 2016 \\
\text { USA, } 1 \text { center }\end{array}$ & $\begin{array}{l}153 \text { women } \\
\text { Overweight or obese stage } 0 \text {-III BC patients } \\
\text { Mean age } 56.5 \text { years } \\
\text { Mean BMI } 31.7 \\
\text { Time from end of systemic treatment to } \\
\text { randomization: at least } 2 \text { months }\end{array}$ & $\begin{array}{l}\text { 6-month intervention } \\
\text { (1) Intervention: individualized anti-inflammatory dietary } \\
\text { prescription and monthly behavior change workshops, } \\
\text { motivational interviewing, and tailoring newsletter } \\
\text { (2) Control: nutritional information at baseline and monthly } \\
\text { AICR brochures with nutritional information. Received } 2 \\
\text { phone calls during follow-up }\end{array}$ & $\begin{array}{l}\text { Change from baseline to } 12 \text { months: } \\
\text { (1) BMI: }-1.3 \\
\text { (2) BMI: }-1.1\end{array}$ \\
\hline $\begin{array}{l}\text { Parekh [16], } 2018 \\
\text { USA, } 1 \text { center } \\
\text { (HEAL-Bca) }\end{array}$ & $\begin{array}{l}59 \text { women } \\
\text { Early-stage BC patients who had completed the } \\
\text { prescribed treatment } \\
\text { Mean age } 58.1 \text { years } \\
\text { Mean BMI } 31.5 \\
\text { Time from diagnosis to randomization: } \\
<6 \text { months }\end{array}$ & $\begin{array}{l}\text { 3-month intervention } \\
\text { (1) Intervention: education to improve nutritional literacy of } \\
\text { BC survivors based on training over a period of } 3 \text { months } \\
(6 \text { sessions: } 12 \mathrm{~h} \text { in total) } \\
\text { (2) Control: nutritional information via AICR brochures } \\
\text { developed for cancer survivors }\end{array}$ & $\begin{array}{l}\text { Change from baseline to } 3 \text { months: } \\
\text { (1) BMI: }-0.69 \\
\text { (2) BMI: }-0.02\end{array}$ \\
\hline $\begin{array}{l}\text { Zuniga [21], } 2019 \\
\text { USA, } 1 \text { center }\end{array}$ & $\begin{array}{l}125 \text { women } \\
\text { Overweight or obese stage } 0 \text {-III BC patients } \\
\text { Stage 0: } 12(8 \%) \text {, stage I: } 35(23 \%) \text {, } \\
\text { stage II: } 38(25 \%) \text {, stage III: } 21(14 \%) \text {, and } \\
\text { unknown: } 19(12 \%) \\
\text { Mean age } 56.5 \text { years } \\
\text { Mean BMI } 31.7 \\
\text { Time from end of systemic treatment to } \\
\text { randomization: at least } 2 \text { months }\end{array}$ & $\begin{array}{l}\text { 6-month intervention } \\
\text { (1) Intervention: individualized anti-inflammatory dietary } \\
\text { prescription and monthly behavior change workshops, } \\
\text { motivational interviewing, and tailoring newsletter } \\
\text { (2) Control: nutritional information at baseline and monthly } \\
\text { AICR Research brochures with nutritional information. } \\
\text { Received } 2 \text { phone calls during follow-up }\end{array}$ & $\begin{array}{l}\text { Change from baseline to } 6 \text { months } \\
\text { (1) Weight: }-0.2 \mathrm{~kg} \\
\text { (2) Weight: }+0.06 \mathrm{~kg}\end{array}$ \\
\hline
\end{tabular}

AICR, American Institute for Cancer Research; BC, breast cancer; IBCE, invasive breast cancer event; ns, not significant; HR, hazard ratio

\section{Study Selection}

We included randomized clinical trials (RCT) that evaluated the effects of dietary interventions (individualized dietary counseling, prescription of a specific diet, or others) compared to usual care in women who received treatment for stage I-III breast cancers. We excluded studies that applied the intervention after 5 years from diagnosis and also studies whose patients were on chemotherapy and/or radiation therapy; hormone therapy was allowed.

The primary outcomes were OS and DFS (5 years after treatment or until the maximum follow-up period). The secondary endpoint was body mass index (BMI). Other endpoints included in the protocol report [13] were waist-to-hip ratio (WHR), estradiol levels, insulin levels, testosterone levels, SHBG levels, and quality of life; these variables were reported for the qualitative analysis.

The evaluation of titles and abstracts and the inclusion of papers and data extraction were conducted by HAVT, FSF, FKA, and MRRF in pairs, independently, and using a standardized form. All disagreements were solved through discussion with the senior author.

\section{Data Extraction}

The data used for the meta-analysis and comparison between usual care and the intervention were the same as in our previous study [10]. Briefly, for the primary outcomes OS and DFS, we used hazard ratios (HRs) with 95\% confidence intervals (CIs). OS was defined as the interval between randomization and death for any cause or censoring of data; DFS was defined as the interval between the randomization and any breast cancer-related event including death, or censoring data. For continuous outcomes, we used the final values of both groups after the intervention, since these were the data most frequently found, to minimize the need for imputations. Studies without both initial and final values were excluded from the analysis. For studies that presented only values of the difference between final results and initial results, the final values were calculated from a simple sum of the variation with the initial value. In this case, the standard deviation (SD) values used were the same as the initial values of the variables. Some final SD values were not reported, e.g., in Parekh et al. [16] and Ramirez et al. [17]; in this event, we used the initial SD. For the study of Chlebowski et al. [18], we used the imputation formula, based on the CI, to obtain the final SD. The studies of Holm et al. [19], Chlebowski et al. [20] and Zuniga et al. [21] were excluded from the meta-analysis due the lack of data for analysis or imputations, and that of Thomson et al. [22] was excluded since it described a population that was likely already described by Rock et al. [23]. 


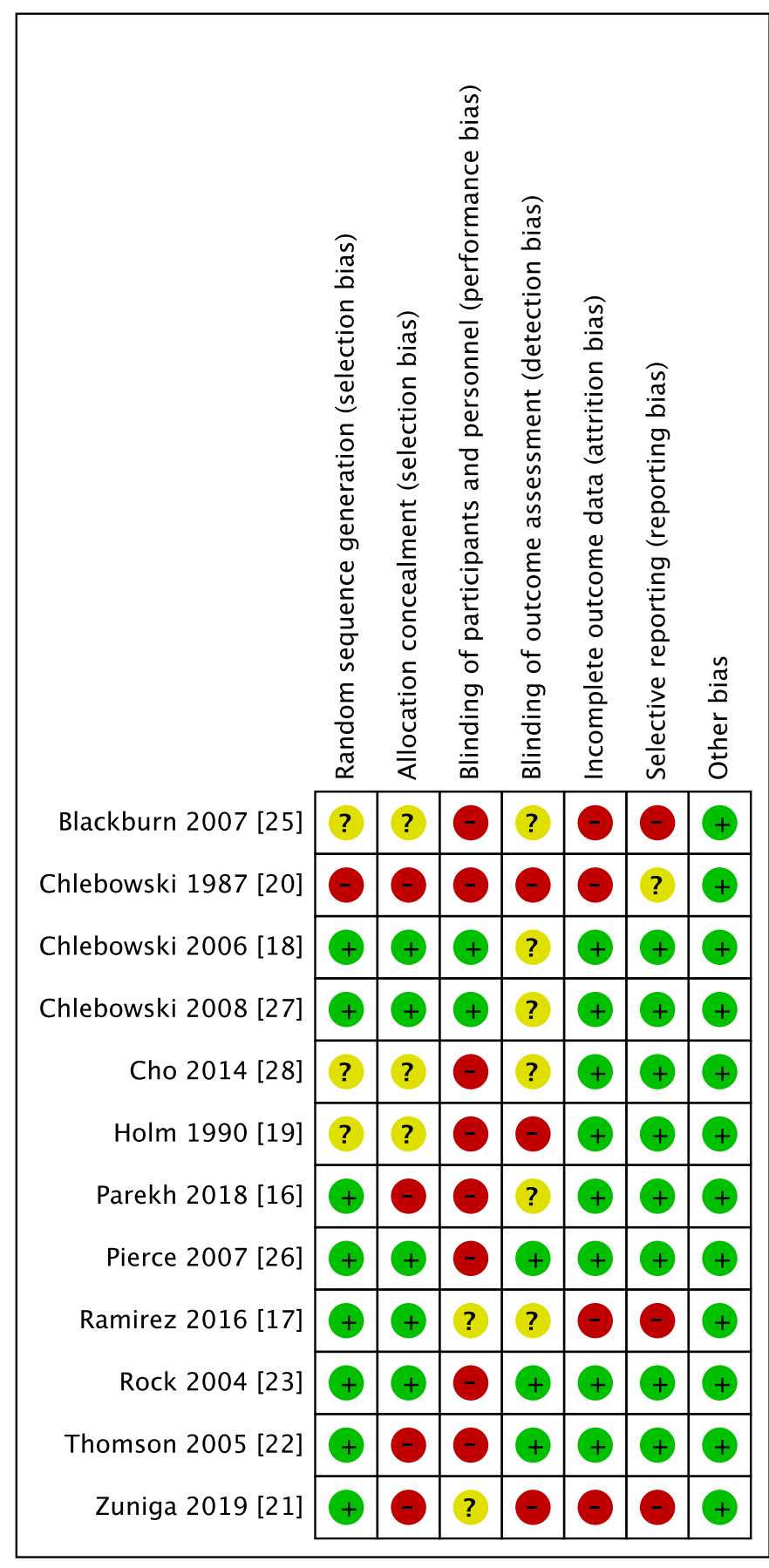

Fig. 2. Risk of bias summary. Created by Review Manager 5.3.

\section{Quality Assessment}

The quality evaluation of all studies was carried out in the same way as for study selection and data extraction, always paired and in accordance with the CHSRI [14] through the Cochrane risk-ofbias tool. The overall quality of evidence was assessed using the Grading of Recommendations, Assessment, Development and Evaluations (GRADE) [24], and was classified as "high," "moderate," "low," or "very low."

Data Synthesis and Analysis

The data were combined using the random-effects meta-analysis model, with the DerSimonian-Laird estimator as a variance estimator, and the treatment effect was estimated using the mean difference (MD) as a summary measure for continuous outcomes. All analyses were performed using $R$ v3.2.1, meta packages v4.9-2. Statistical heterogeneity was assessed in each meta-analysis using the statistic $I^{2}$, and heterogeneity was considered substantial if $I^{2}$ was $>50 \%$. Publication bias was assessed using a funnel-plot, and its effect on the interpretation of the results was evaluated by a trim-and-fill computation.

\section{Results}

\section{Literature Search}

A total of 23,249 records were identified in the database search. There were 4,308 duplicated records, leaving 18,941 for title and abstract analysis; 18,863 records were excluded, leaving 78 studies for full-text analysis. After that, 12 studies provided data for the qualitative analysis $[16-23,25-28], 7$ of which were included in the metaanalysis. The flowchart of the search is presented in Figure 1. Study characteristics are presented in Table 1. The risk of bias in the studies is summarized in Figure 2 (also in online suppl. Fig. 3).

\section{Study Characteristics}

A total of 6,087 patients were allocated in 7 studies. The mean duration of interventions was 15.7 months (range 2-60 months). The maximum follow-up period was 108 months and the minimum was 2 months. Two studies reported OS and DFS data, i.e., the WINS [27] and WHEL [26] trials with 108 and 87.6 months of follow-up, respectively.

\section{Outcomes}

Regarding the primary outcomes, the interventions did not promote a significant mortality reduction in all subset of patients (HR 0.91; 95\% CI 0.77-1.07, $p=0.25$, $I^{2}=7 \%$, low-quality evidence) (Fig. 3). Similarly, there was no improvement in DFS in the intervention group (HR 0.92; 95\% CI 0.79-1.08, $p=0.31, I^{2}=52 \%$, very lowquality evidence) (Fig. 4). Due to a trend of better DFS for ER-negative and PR-negative patients allocated in the intervention group in WINS, we performed a subgroup analysis, stratifying participants with hormone receptorpositive and hormone receptor-negative tumors. This analysis showed no benefits of dietary interventions in DFS (HR 0.87; 95\% CI 0.68-1.1, $p=0.23, I^{2}=62 \%$, highquality evidence) (Fig. 4).

General dietary interventions were not associated with a reduced BMI $(-0.32$; $95 \%$ CI -0.95 to $0.30, p=0.31$, $I^{2}=21 \%$, very-low quality evidence), but there was a significant reduction $(-0.67 ; 95 \%$ CI -1.14 to -0.21 , very low-quality evidence) (Fig. 5) in subjects who received a specific diet instead of counseling or other types of intervention. 


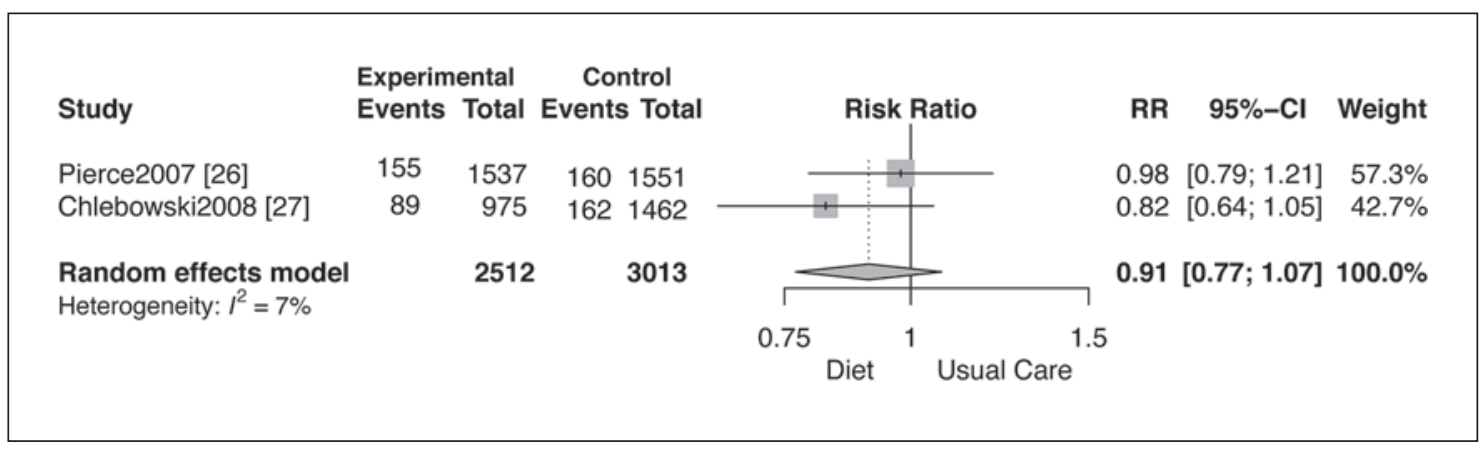

Fig. 3. Forest plot for overall survival. Created by RStudio v1.1.453.

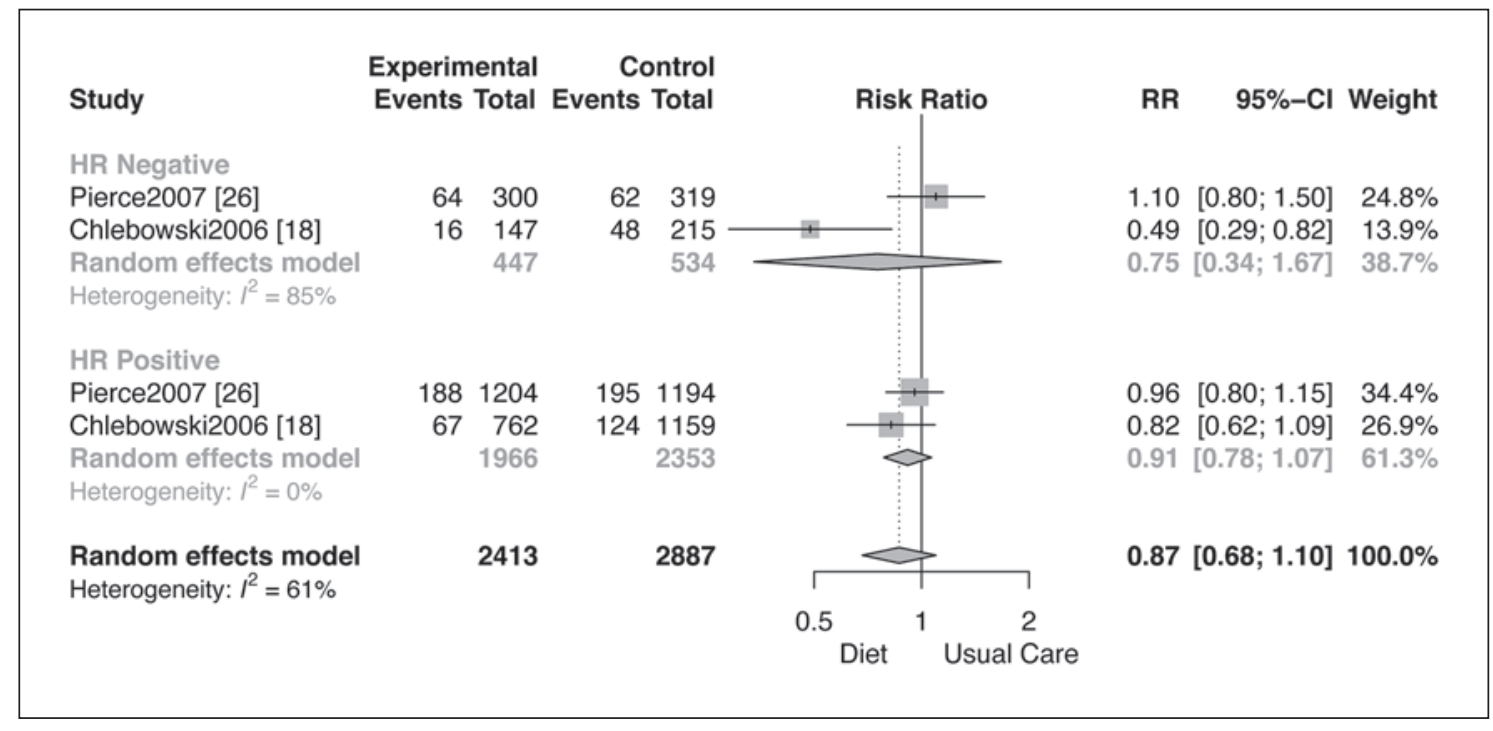

Fig. 4. Forest plot for DFS sorted by hormonal receptor status (ER-positive and/or PR-positive vs. hormone receptor-negative). Created by RStudio v1.1.453.

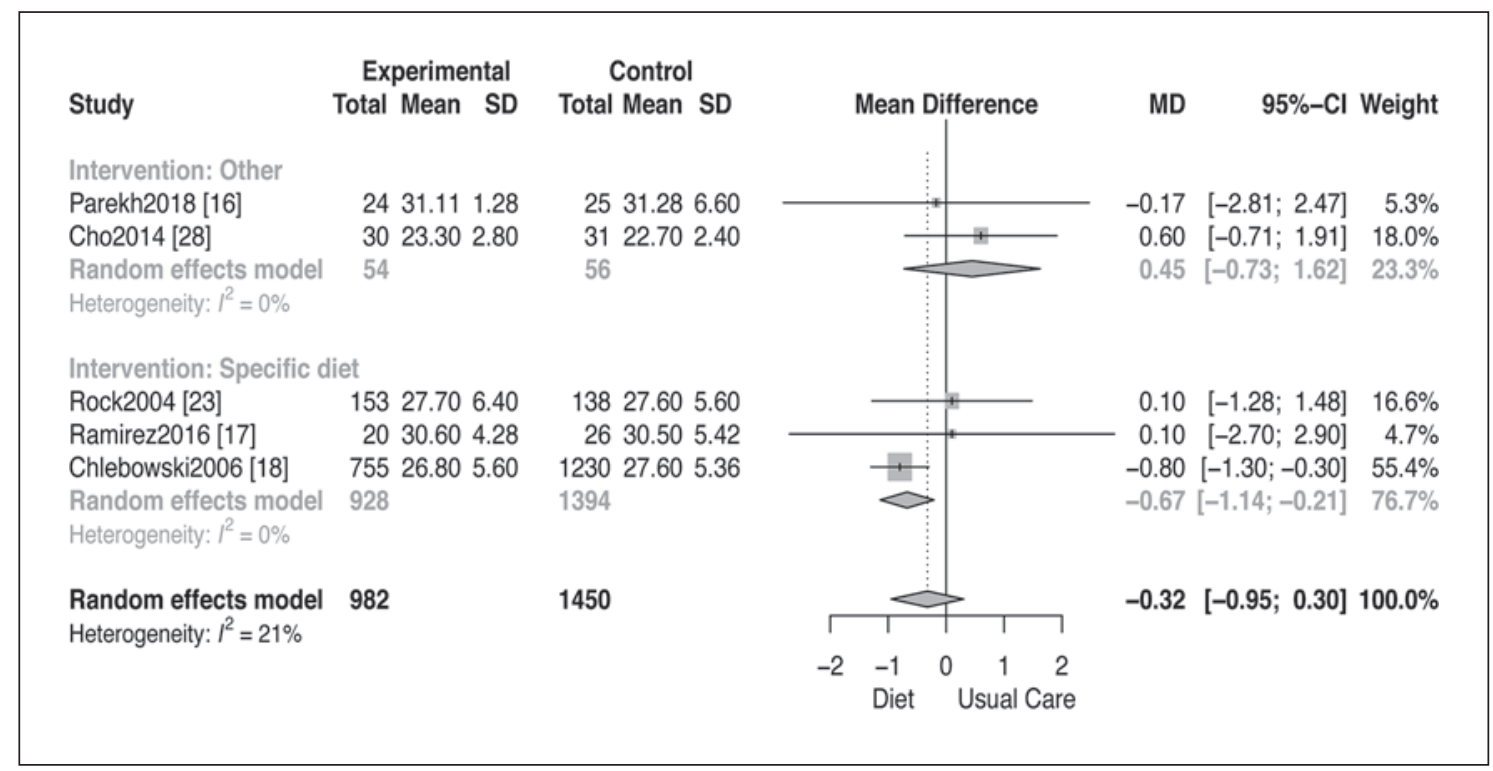

Fig. 5. Forest plot for BMI reduction sorted by type of intervention. Created by RStudio v1.1.453. 
The Egger test for asymmetry and publication bias was not conducted since there were $<10$ trials. Visual asymmetry was used as described by Sterne et al. $[29,30]$. Since there were only a few outcomes, trim-and-fill analysis was performed for all outcomes and there was no loss of significance after that (online suppl. Fig. 1, 2).

\section{Discussion}

This study is the first meta-analysis of RCT that reported data on OS and DFS of dietary interventions exclusively, without combining physical activity and other interventions. Other meta-analyses assessed the same outcomes but included observational studies [6]. Our goal was to collect the best evidence available; we therefore chose to include only RCT comparing the impact of dietary interventions against usual care.

Our meta-analysis provides data on the OS and DFS of 5,525 patients from the WINS [27] and WHEL [26] trials. There were no differences in outcomes compared to usual care with regard to OS or DFS, even when stratifying by hormonal receptor status. DFS was better for patients allocated to the intervention group in WINS, mainly for those with ER-/PR-negative tumors, but this difference was not shown in the WHEL trial. There are some aspects of these studies to point out. First, in WINS there was a difference in BMI favoring the intervention group, which could explain better relapse-free survival and the trend for a better OS. In WHEL, there were no differences between groups in terms of BMI, either at baseline or the end of the study. Second, WINS reported a high rate of missing dietary intake data at the 5-year assessment, i.e., for only $39 \%$ of the intervention group and $44 \%$ of the control group. Third, the subjects were different in the 2 studies. WINS had more patients with stage I disease (54 vs. $38 \%$ ) and less stage II and III patients ( 42 vs. $57 \%$ and 3.5 vs. $5 \%$, respectively). WHEL did not include patients with tumors $<1 \mathrm{~cm}$ or patients aged $>70$ years at randomization. Moreover, treatment regimens, age, and prognostic factors were different in the 2 trials.

We found a slight difference in terms of BMI reduction favoring the group whose intervention was the prescription of a specific diet. The interventions in all 5 studies, including WINS and WHEL, did not aim to reduce weight by means of a hypocaloric diet. Only in WINS there was a reduction in $\mathrm{BMI}$ in the intervention arm, mainly due to significantly less fat intake $(-8 \%)$ than in the control arm.

Recently, Chlebowski et al. [31] published an update of the Women's Health Initiative (WHI) Dietary Modification which randomized 48,835 postmenopausal women with no prior breast cancer to receive a 8.5 -year low-fat diet or usual diet intervention. After 19.6 years of follow- 
up, there was a nonsignificant difference in new cases of breast cancer that favored the intervention group (HR $0.95,95 \%$ CI $0.89-1.02$ ), but fewer deaths related to breast cancer (HR 0.85, 95\% CI 0.74-0.96). Despite not being the same population as in our meta-analysis, this result sheds light on the importance of recommending highquality diets for all postmenopausal women with breast cancer.

Our meta-analysis has several limitations. First, there was a lack of good-quality data on anthropometric measures accordingly to GRADE quality assessment (very low-quality evidence; Table 2). Second, some of the studies did not report the pathologic features of tumors, such as hormone receptor and HER2 status. Third, 2 studies $[17,21]$ included only overweight or obese women whereas the great majority of studies included patients in all BMI groups. Finally, the interventions were heterogeneous across studies, in terms of the diet that was prescribed (regarding fat content, caloric intake, etc.), the duration of the intervention, and the way patients were supervised during the study, thus explaining why (in some instances) a significant weight loss was achieved and sometimes it was not. This heterogeneity might explain why a more robust benefit was not seen in this analysis; it makes a point for ongoing investigation for the best dietetic interventions in survivors of breast cancer.

Considering all limitations, our meta-analysis provided data on OS and DFS of early breast cancer survivors who underwent dietetic interventions after completing breast cancer treatment. We found no differences in OS and DFS in the groups, probably because the interven- tions did not significantly reduce the BMI. Despite the lack of evidence supporting dietary interventions, survivors are oriented to maintain or reduce weight through a high-quality food diet and low caloric intake because this intervention is cheap and has no significant adverse effects. Therefore, interventions targeting weight control and healthier behaviors must be assessed by high-quality evidence studies.

\section{Conflict of Interest Statement}

The authors declare there were no conflicts of interest.

\section{Funding Sources}

This research did not receive any specific grant from funding agencies in the public, commercial, or not-for-profit sectors.

\section{Author Contributions}

H.A.V.T.: conceptualization, methodology, formal analysis, investigation, data curation, writing (original draft, review, and editing), visualization, and project administration; F.S.F.: conceptualization, methodology, formal analysis, investigation, and writing (review and editing); F.K.A.: conceptualization, methodology, investigation, and writing (review and editing); M.R.R.F.: methodology, formal analysis, and investigation; R.A.R.: conceptualization, methodology, writing (review and editing), and supervision; D.D.R.: conceptualization, methodology, investigation, writing (review and editing, visualization), and supervision.

\section{References}

1 Bray F, Ferlay J, Soerjomataram I, Siegel RL, Torre LA, Jemal A. Global cancer statistics 2018: GLOBOCAN estimates of incidence and mortality worldwide for 36 cancers in 185 countries. CA Cancer J Clin. 2018 Nov;68(6): 394-424.

2 Janni W. Breast Cancer - a Lifestyle Disease? Breast Care (Basel). 2018 Apr;13(2):84-5.

3 Irwin ML, McTiernan A, Baumgartner RN, Baumgartner KB, Bernstein L, Gilliland FD, et al. Changes in body fat and weight after a breast cancer diagnosis: influence of demographic, prognostic, and lifestyle factors. J Clin Oncol. 2005 Feb;23(4):774-82.

4 Vance V, Mourtzakis M, McCargar L, Hanning R. Weight gain in breast cancer survivors: prevalence, pattern and health consequences. Obes Rev. 2011 Apr;12(4): 282-94.

5 Protani M, Coory M, Martin JH. Effect of obesity on survival of women with breast cancer: systematic review and meta-analysis. Breast Cancer Res Treat. 2010 Oct;123(3):627-35.

6 Chan DS, Vieira AR, Aune D, Bandera EV, Greenwood DC, McTiernan A, et al. Body mass index and survival in women with breast cancer-systematic literature review and metaanalysis of 82 follow-up studies. Ann Oncol. 2014 Oct;25(10):1901-14.

7 Goodwin P, Esplen MJ, Butler K, Winocur J, Pritchard K, Brazel S, et al. Multidisciplinary weight management in locoregional breast cancer: results of a phase II study. Breast Cancer Res Treat. 1998 Mar;48(1):53-64.

8 Holmes MD, Chen WY, Feskanich D, Kroenke $\mathrm{CH}$, Colditz GA. Physical activity and survival after breast cancer diagnosis. JAMA. 2005 May;293(20):2479-86.

9 Hayes SC, Steele M, Spence R, Pyke C, Saunders C, Bashford J, et al. Can exercise influence survival following breast cancer: results from a randomised, controlled trial. J Clin Oncol. 2017;35(15_suppl):10067.

10 Soares Falcetta F, de Araújo Vianna Träsel H, de Almeida FK, Rangel Ribeiro Falcetta M, Falavigna M, Dornelles Rosa D. Effects of physical exercise after treatment of early breast cancer: systematic review and metaanalysis. Breast Cancer Res Treat. 2018 Aug; 170(3):455-76.
11 Zhang S, Folsom AR, Sellers TA, Kushi LH, Potter JD. Better breast cancer survival for postmenopausal women who are less overweight and eat less fat. The Iowa Women's Health Study. Cancer. 1995 Jul;76(2):27583.

12 Jain M, Miller AB, To T. Premorbid diet and the prognosis of women with breast cancer. J Natl Cancer Inst. 1994 Sep;86(18):1390-7.

13 Falavigna M, Lima KM, Giacomazzi J, Paskulin D, Hammes LS, Ribeiro RA, et al. Effects of lifestyle modification after breast cancer treatment: a systematic review protocol. Syst Rev. 2014 Jul;3(1):72.

14 Higgins J, Green S, editors. Cochrane Handbook for Systematic Reviews of Interventions Version 5.1.0 [updated March 2011]. The Cochrane Collaboration; 2011. Available from: http://handbook.cochrane.org.

15 Liberati A, Altman DG, Tetzlaff J, Mulrow C, Gøtzsche PC, Ioannidis JPA, et al. The PRISMA statement for reporting systematic reviews and meta-analyses of studies that evaluate healthcare interventions: explanation and elaboration. BMJ. 2009;339:b2700. 
16 Parekh N, Jiang J, Buchan M, Meyers M, Gibbs H, Krebs P. Nutrition Literacy among Cancer Survivors: Feasibility Results from the Healthy Eating and Living Against Breast Cancer (HEAL-BCa) Study: a Pilot Randomized Controlled Trial. J Cancer Educ. 2018 Dec;33(6):1239-49.

17 Ramirez AG, Muñoz E, Long-Parma D, Mendoza KD, Holden AEC, Wargovich MJ. Abstract A66: An anti-inflammatory dietary intervention to reduce breast cancer recurrence risk: Preliminary data from a pilot study. Cancer Epidemiol Biomarkers Prev. 2016;25(3 Supplement):A66.

18 Chlebowski RT, Blackburn GL, Thomson CA, Nixon DW, Shapiro A, Hoy MK, et al. Dietary fat reduction and breast cancer outcome: interim efficacy results from the Women's Intervention Nutrition Study. J Natl Cancer Inst. 2006 Dec;98(24):1767-76.

19 Holm LE, Nordevang E, Ikkala E, Hallström L, Callmer E. Dietary intervention as adjuvant therapy in breast cancer patients-a feasibility study. Breast Cancer Res Treat. 1990 Sep; 16(2):103-9.

20 Chlebowski RT, Nixon DW, Blackburn GL, Jochimsen P, Scanlon EF, Insull W Jr, et al. A breast cancer Nutrition Adjuvant Study (NAS): protocol design and initial patient adherence. Breast Cancer Res Treat. 1987 Oct;10(1):21-9.

21 Zuniga KE, Parma DL, Muñoz E, Spaniol M, Wargovich M, Ramirez AG. Dietary interven- tion among breast cancer survivors increased adherence to a Mediterranean-style, anti-inflammatory dietary pattern: the Rx for Better Breast Health Randomized Controlled Trial. Breast Cancer Res Treat. 2019 Jan;173(1): 145-54.

22 Thomson CA, Rock CL, Giuliano AR, Newton TR, Cui H, Reid PM, et al.; Women's Healthy Eating \& Living Study Group. Longitudinal changes in body weight and body composition among women previously treated for breast cancer consuming a high-vegetable, fruit and fiber, low-fat diet. Eur J Nutr. 2005 Feb;44(1):18-25.

23 Rock CL, Flatt SW, Thomson CA, Stefanick ML, Newman VA, Jones LA, et al. Effects of a high-fiber, low-fat diet intervention on serum concentrations of reproductive steroid hormones in women with a history of breast cancer. J Clin Oncol. 2004 Jun;22(12):2379-87.

24 Balshem H, Helfand M, Schünemann HJ, Oxman AD, Kunz R, Brozek J, et al. GRADE guidelines: 3. Rating the quality of evidence. J Clin Epidemiol. 2011 Apr;64(4):401-6.

25 Blackburn GL, Wang KA. Dietary fat reduction and breast cancer outcome: results from the Women's Intervention Nutrition Study (WINS). Am J Clin Nutr.2007 Sep;86(3):s87881.

26 Pierce JP, Natarajan L, Caan BJ, Parker BA, Greenberg ER, Flatt SW, et al. Influence of a diet very high in vegetables, fruit, and fiber and low in fat on prognosis following treatment for breast cancer: the Women's Healthy Eating and Living (WHEL) randomized trial JAMA. 2007 Jul;298(3):289-98.

27 Chlebowski RT, Blackburn GL, Hoy MK, Thomson CA, Giuliano AE, McAndrew P, et al. Survival analyses from the Women's Intervention Nutrition Study (WINS) evaluating dietary fat reduction and breast cancer outcome. J Clin Oncol. 2008;26(15_suppl):522.

28 Cho SW, Kim JH, Lee SM, Lee SM, Choi EJ, Jeong J, et al. Effect of 8-week nutrition counseling to increase phytochemical rich fruit and vegetable consumption in korean breast cancer patients: a randomized controlled trial. Clin Nutr Res. 2014 Jan;3(1):39-47.

29 Sterne J, Egger M, Smith D. Investigating and dealing with publication and other biases. In: Egger M, Smith D, Altman D, editors. Systematic revies in health care: meta-analysis in context. London: BMJ Books; 2001

30 Sterne JA, Egger M. Funnel plots for detecting bias in meta-analysis: guidelines on choice of axis. J Clin Epidemiol. 2001 Oct;54(10):104655.

31 Chlebowski RT, Aragaki AK, Anderson GL, Pan K, Neuhouser ML, Manson JE, et al.; Women's Health Initiative. Dietary Modification and Breast Cancer Mortality: Long-Term Follow-Up of the Women's Health Initiative Randomized Trial. J Clin Oncol. 2020 May; 38(13):1419-28. 